\title{
Orientation, Supervision and University Student-teacher Performance in Oyo State, Nigeria
}

\author{
Afolakemi 0. Oredein \\ Department of Educational Management \\ Faculty of Arts \& Education \\ Lead City University, Ibadan, Nigeria \\ Monilola D. Oyetade \\ Department of Guidance \& Counselling \\ Faculty of Arts \& Education \\ Lead City University, Ibadan, Nigeria.
}

\begin{abstract}
This study examined the influence of teaching practice orientation and supervision on university student-teachers' performance in selected public secondary schools in Ibadan. The population consisted of all the penultimate and final year of the Faculty of Education students in the sampled instituitons. The sample was made of two hundred (200) student-teachers from 300 and 400 levels respectively and twenty cooperating teachers making two hundred and ten (210). Multistage and simple random sampling techniques were used to select the sample. For data collection, developed structured questionnaire was adopted and three research questions and two research hypotheses were formulated and tested at $5 \%$ level of significance. The instrument was given face validity and the reliability Cronbach Alpha was 0.86. Descriptive research design was used and the data collected was analyzed using descriptive and inferential statistics such as ANOVA and t-distribution test was used to analyze the gender difference. Among others, the result revealed a combined influence of teaching practice orientation and supervision $(\mathrm{F}=10.87, \mathrm{P}<0.05)$ on the university possessive-teacher performance during the teaching practice exercise. It was recommended that teaching practice committee of each university should make sure that possessive-teachers are posted to the practicing schools where they are needed.
\end{abstract}

Keywords: supervision, teaching practice, orientation, student-teacher

\section{INTRODUCTION}

Teaching practice exercise is an essential part of teacher training in an educational based tertiary institution. Functionally, it exposes the student-teachers to the actual teaching and learning processes while in school, thereby, regarded as grounds for future teachers. Before the teaching practice exercise, student-teacher would have offered a course titled 'Micro teaching' hence, teaching practice exercise is the period whereby the student-teacher puts into practice all the theories that have been taught and learnt. On getting to the cooperating school, the student-teacher watches the subject teachers (also known as the cooperating teacher) teach in order to acquire skills, strategies and the technical-know-how in the classroom activities. Performance during teaching practice provides some basis for predicting the future success of the student-teacher. In order to enhance quality education, theoretical knowledge alone cannot sufficiently equip a trainee for the arduous task of learning hence he or she must be adequately prepared for the task ahead. Teaching practice exercise is for a period of six weeks and be done at two different levels of academic year (300 level and 400 level). 
The National Policy on Education (2004) stressed that "no matter the efficiency of pre-service training given to teachers, there will necessarily be areas of inadequacies". To bridge this gap the students-in-training must be exposed to classroom situation (teaching-learning activities) and supervised by his or her trainers. This affords at first hand the actual work of a teacher in a typical classroom situation and provides the student-teacher the opportunity to meet learners in their natural setting and to put into practice the theories acquired in pre-service training.

Teaching practice exercise refers to the range of experiences to which student-teachers are exposed in the actual teaching-learning environment (Ngidi \& Sibaya, 2003; Marais \& Meier, 2004). In the light of this, teaching practice exercise is seen to prepare students for maximum practical and professional training in the field of education by offering them with the following: experience through participation and observation under the auspices of the institutions to which students are attached, professional skills which are acquired through planned programmes so as to meet and satisfy the needs of the profession as well as the environment to which the students are being prepared for, and although teaching practice exercise is meant to achieve the above-stated goals, some lapses could be deduced and this could be responsible for its effectiveness.

From experience, student-teachers always complain of so many challenges during teaching practice exercise like; uneasy accessibility to the cooperating schools, extra expenses on their budgets, too large number of students in the classroom, non cooperation of the cooperating teachers, unruly behavior of the students, and poor conducive learning environments among others. Therefore, there is need for teaching practice orientation, monitoring and having an adequate supervision if teaching practice exercise must achieve its goal(s). This work therefore assessed teaching practice orientation, supervision and university student-teachers' performance in Oyo State, Nigeria.

\section{The Teaching Profession}

Teaching is the process of impacting knowledge on someone or a group of people while profession is a career or occupation that involves prolonged training and formal qualification. Teaching is an act of "causing to learn", nothing has been given until it has been taken; nothing has been taught until it has been learnt. Teaching is one of the noble professions with the greatest responsibilities which so many people in the society do not recognize. For an occupation to be classified as a professional, services in a determined field should have been provided through formal training with expert knowledge, possesses professional culture, ethics, has admission control, owns professional establishments, and is considered as a profession by the society (Erden, 2007). From this perspective, one can say that a professional is someone who is not an amateur but committed to a career and to public service.

Teaching profession is the educational career which has gone through a series of structured training and to impact the expected knowledge on someone or a group of learners. The knowledge of how children learn is the first essential for success in teaching and that accounted for professionalism of teaching.

According to Faulkner and Cook (2006), teaching as a profession is an inestimable significance as an instrument to effect personal and national development. Hence effective teaching should ensure meaningful internalization of sufficient knowledge, skills and habits in order to produce responsible competent individuals. Teaching is the specialized application of knowledge, skills and attributes designed to provide unique service to meet the educational needs of the individual and society. Also, apart from providing students with learning opportunities to meet 
curriculum outcomes, teaching profession emphasizes the development of core values and guides students in their social relationships by developing their self-concept.

A teacher has professional knowledge and skills like communication skills, gained through formal preparation and experience and that is why teaching practice is important to the teaching profession. Teachers set nude the mysteries of the world by training the minds of students to survey, discover, search and investigate things. To teachers, knowledge does not end because it is being passed on to the next generation. The process of teaching includes understanding and adhering to legal and legislated frameworks and policies; identifying and responding to student learning needs; providing effective and responsive instruction; assessing and communicating student learning; developing and maintaining a safe, respectful environment conducive to student learning. More so, to establish and maintain professional practice and these processes help to contribute to the holistic development of students without any bias or discrimination. In view of this, it is very crucial for teachers-in-training to be well groomed and acquire the necessary professional skills like classroom management, teacherstudent good relationship, teamwork, mentoring and time management that will make them to excel in the teaching profession.

In Nigeria, just as other professions are facing challenges so is teaching profession, such challenges, like global age, insufficient funding, and untrained people in the teaching profession among others. Therefore, it is important for the student-teachers to acquire the necessary trainings to meet up with these challenges and to have positive influence on the learners.

\section{Teaching Practice in the Art of Teaching}

Teaching practice exercise is an exercise or the art of teaching for a given period of time with the aim of improving the student-teachers' ability to teach, and impact the expected knowledge effectively as a teacher. Normally, teaching practice exercise involves posting the studentteachers out to different cooperating schools specified by the school authority concerned for a period of weeks depending on each institution. Damola (1991) asserted that no education programme is complete without a teaching practice experience which is meant to equip students in becoming a professional teacher.

According to Schön (1982), Shulman (1986), amd Anniong (1988) experience is educative only with reflection. This suggests that the improvement of the teacher-learning process requires acknowledging and building upon teachers' experiences, and promoting reflection on those experiences which in turn influence the development of practical knowledge which relates to the teacher as a person. Bryk (1988) described good teaching as an "intensely personal activity". The practical knowledge is the teacher's knowledge and belief about the way the teacher is teaching which is developed through an integrative process rooted in classroom management. Practical knowledge helps and guides the teacher in the classroom. Teacher's practical knowledge could be based on existing theories which the teacher has now builts and developed over years of teaching experience.

Experience as a learner and teachers, of course, is personal and considered as the most important element. However, there are other aspects related to who the teachers are, and perhaps more importantly, their perceptions and beliefs about themselves as learners and teachers. Clandinin (1986) and Cladinin and Connelly (1986) suggested, through a case study that the teacher's personal narratives or constructions of their biographies interact with particular situations to help teachers acquire practical knowledge. 
Therefore, teaching provides individuals the opportunity to observe themselves. It goes beyond standing in front of a class with a chalk or a maker in your hand and be talking to the students. Teaching requires a whole lot of technicalities and adequate experience. To enhance outstanding performance in teaching practice, orientation for teachers'in-training is highly essential and this usually takes place before the commencement of teaching practice. This is coordinated by the experts (lecturers) in different disciplines. The teaching practice lesson plan booklet which is usually supplied by some schools is given to the students to understudy. This booklet contains students bio-data, details about the training school, topic and sub-topic of each lesson, subject to be taught, term, week of the term, week, date, period/duration, average of the students in class, instructional materials, reference materials. The Part B of the lesson plan includes Behavioral Objective, Previous Knowledge/Entry behavior and Instructional Strategy. In addition, development of the lesson where the teachers'-in-training discusses the steps he or she will follow in teaching the topic which starts with the introduction of the lesson. The lesson introduction is very important to the teacher because you need to capture the interest of the students you are teaching right from the beginning and sustain it to the end.

The student-teacher is always encouraged during orientation to explain each step in their lesson plan so that when the supervisors come around they will know what they are teaching the students and this basically will influence their marks. Also, during orientation, studentteachers are being taught some other areas like, time management, classroom management, teacher-student relationship, school community relationship, usage of instructional materials for effective teaching, and the full completion of the lesson plan before going to teach.

Furthermore, in the column for summary, the student-teacher is expected to mention just the important points while evaluating the lesson, the student-teacher is expected to find out whether the students had mastered what he or she had taught in relation to behavioural objectives. For example, if the topic is on English grammar, assuming the topic is on "Noun", the student-teacher can write "The students can differentiate between countable and uncountable Nouns and so on.

Also, key topics that can be discussed during teaching practice orientation include classroom management, time management, mode of dressing, student-teachers' behavior/comportment of course, Teaching practice code of conduct, that is, "Dos and Don'ts" to instill discipline. Orientation for student-teachers is always an interactive forum because the experts are not only to educate the students but must also be ready to answer questions asked by them. In exposing student-teachers to real life classroom experiences adequate supervision must be ensured by the qualified and trained professional teachers.

To achieve Teaching practice objectives, each Teaching practice supervisor is expected to have good mastery of his or her subject, be humble, fair, competent and demonstrate a total commitment to the Teaching practice exercise. In all the tertiary institutions, supervision of the student-teachers is usually carried out by the teachers (experts) in that institution. Supervision has to do with all efforts designed for the school officials toward providing leadership to teachers, with the intention of improving classroom instruction and not "to nail any student on the cross! Teaching practice supervision helps to get feedback from the exercise in order to assist the student teachers to improve on their teaching. Ijaya (1991) stressed that the process of supervision has to do with the supervisor personally visiting the classroom to observe the teaching-learning process for the purpose of assisting the teacher to "improve on his or her competence or to enhance learners' learning and attainment of educational objectives. Therefore, the supervisors are expected to be firm in their dealings with the student-teachers, 
maintain cordial relationship with the participating schools and the community to which they are posted.

For effective supervision, it is imperative for the supervisors to look into the following areas before decision-making. These are: preparation, assessment and feedback. At the preparatory stage, the supervisor collects the student-teachers' lesson plan for vetting before the commencement of teaching in order to determine the adequacy of the lesson plan in relation to the objective(s) of the lesson. Also, for proper assessment, the supervisor observes the students teach and marks are awarded based on the performance of each skill identified in the section of the assessment sheet/form. Marks are allocated on lesson presentation (from simple to complex) mastery of the topic, effective use of instructional, materials, classroom management, fluency and grammatical personality and mode of dressing. The feedback stage takes place at the end of the entire supervision exercise during the day. All the studentteachers assessed are summoned for briefing with intention to tell them their performances, identified their area of strengths and weaknesses.

It has been observed from experience that student-teachers experience various problems varying from rejection by the school where they are posted, poor learning environment of the school (congestion in the classroom, poor ventilation, and poor facilities for learning, among others), schools not distributing schedules according to the student-teacher area of specialization, and government not given adequate support to the teaching practice exercise programme. To this end, this study investigates the influence of teaching practice orientation and supervision on the university student-teacher performance in the selected public secondary schools in Ibadan, Oyo state, Nigeria.

\section{RESEARCH QUESTIONS}

1. What are the challenges encountered by student-teachers during teaching practice exercise?

2. What are the perceived contributions of teaching practice exercise to student-teacher teaching skill?

3. What is the assessment of the cooperating teachers on the performance of the studentteacher during the exercise?

\section{RESEARCH HYPOTHESES}

1. There is no combined significant influence of teaching practice orientation and supervision on the possessive-teacher performance.

2. There is no relative significant influence of teaching practice orientation and supervision on the university student-teacher performance in the selected public secondary schools in Ibadan.

\section{METHOD}

The study adopted the descriptive survey research design. The population consisted of 300 level and 400 level of the Faculty of Education students in Ibadan, Oyo State. There are two universities in Ibadan, one public and one private. Students have been stratified into levels (300 and 400 level), while multi-stage and random sampling techniques were used to select fifty (50) students from each level and universities making two hundred (200) samples. Also, ten (10) public secondary schools were randomly selected from practicing schools in Ibadan, Oyo State, Nigeria and two cooperating teachers were selected per school making 20, having a grand total of two hundred and twenty (220) respondents. 
Two instruments were designed; one for the student-teachers while the other was for the cooperating teachers. The instrument designed for the student-teachers was titled "Teaching practice orientation and supervision on the university student-teacher performance (TPOSUSTP)" while the one for the cooperating teachers was an assessment sheet to assess the student-teachers after the six-weeks teaching practice exercise. TPOSUSTP was divided into three sections; section A contained items on the respondents biographical information and items on challenges that student-teachers faced during teaching practice. Section B, contained items on teaching practice orientation, and section $\mathrm{C}$ has items on supervision.

To ensure the validity of the instrument used for the study, the draft questionnaire was administered to ten education students that were not included in the samples (pilot survey). The suggestions and corrections were incorporated into the final draft before administering the instrument on the field.

For this study, the reliability test was done on the instrument and the value of the Cronbach's Alpha Coefficient method was used to measure the consistency of the instrument which yielded $\alpha=0.81$, which indicates that the instrument was reliable.

The statistical tools used to analyze the data collected were; frequency percentage to analyze the bio-data information of the respondents, descriptive analysis of frequency count distribution and mean score for research questions and Multiple Regression Analysis (ANOVA) for the hypotheses and t-test for the gender difference at $5 \%$ level of significance.

\section{RESULTS}

Research Question One: What are the challenges encountered by student-teachers during teaching practice exercise?

\section{Table 1: Challenges Encountered by Student-teachers During Teaching Practice}

\section{Challenges Encountered}

1. Accommodation for the student-teacher

2. Problem of Instilling Discipline in the classes

3. Rejection at will by the practicing school

4. Feeling nervous when supervised by their lecturers/supervisors

5. Problem of using various methods of teaching

6. Time Management

7. How to handle different levels of students

8. Lack of facilities in the practicing schools

9. Poor classroom management

10. Too many students in a class

$\begin{array}{cc}\text { Very High(\%) } & \text { High(\%) } \\ 44 & 38 \\ 18 & 24 \\ 18 & 38 \\ & \\ 46 & 48 \\ 32 & 28 \\ 40 & 30 \\ 39 & 26 \\ 52 & 33 \\ 36 & 34 \\ 50 & 28\end{array}$

Survey, 2016

$\begin{array}{cc}\text { Average(\%) } & \text { Low (\%) } \\ 16 & 2 \\ 46 & 12 \\ 28 & 16 \\ & \\ 2 & 4 \\ 34 & 6 \\ 20 & 14 \\ 29 & 6 \\ 9 & 6 \\ 15 & 10 \\ 15 & 7\end{array}$
14

Table 1 above revealed that the highest challenge that student-teachers encountered during teach practice exercise is the lack of facilities (52\%) in the practicing schools. In so many public schools, some students sit on the floor because there are no enough seats and tables. Some students bring their seats and tables from home, some students share with their friends while some students lean on the walls when classes are going on. This is followed by too many students in a class making the class congested (50\%). Sometimes there can be up to hundred and twenty (120) in a class which lead to survival of the fittest. This is followed by feeling nervous when supervised by their supervisors or lecturers (46\%) during the teaching practice exercise. The least perceived challenge(s) encountered by student-teacher during teaching 
practice is rejection at will by the practicing school (18\%) and problem of instilling discipline in the classes. This study is in line with Saricoban (2010), who identified in his study, problems that student-teachers encountered during teaching practice which vary from non availability of textbooks, poor classroom environment and absence of supplementary materials for effective teaching-learning process.

Research Question Two: What are the perceived contributions of teaching practice exercise to student-teacher teaching skill?

Table 2: Contributions of Teaching Practice Exercise to Student-teacher Teaching Skills

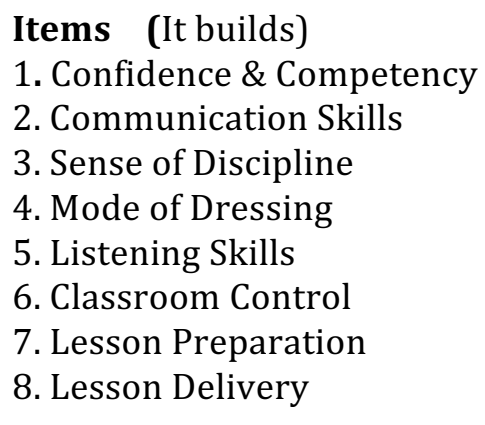

Items (It builds)

1. Confidence \& Competency

2. Communication Skills

4. Mode of Dressing

5. Listening Skills

6. Classroom Control

8. Lesson Delivery

Very High(\%)
60
44
42
32
42
38
56
57

Survey, 2016

$\begin{array}{ccc}\text { High(\%) } & \text { Average(\%) } & \text { Low(\%) } \\ 40 & 0 & 0 \\ 54 & 2 & 0 \\ 52 & 6 & 0 \\ 60 & 8 & 0 \\ 52 & 6 & 0 \\ 48 & 14 & 0 \\ 40 & 4 & 0 \\ 41 & 2 & 0\end{array}$

Table 2 above showed that teaching practice exercise builds confidence and competency in student-teachers $(60 \%)$. The next highest contribution of the teaching practice exercise to student-teacher teaching skill is lesson delivery that, teaching practice exercise helps and builds the lesson delivery of the student-teachers (57\%) with time and this is followed by lesson preparation. The student-teachers indicated that teaching practice builds the way they prepare lesson gradually. Teaching practice also inculcate sense of discipline (42\%) in the student-teachers. The least contribution is class control (38\%). There are research works that agreed with this finding (Emerole \& Muraina, 2015; Dibbon, 2004; Schaefer, 2001; and Younghusband 2000). Emerole \& Muraina opined that teaching practice is positively related to the lesson preparation and presentation.

Research Question Three: What is the assessment of the cooperating teachers on the performance of the student-teacher during the exercise?

Table 3: Assessment of the Cooperating Teachers on the Performance of the Student-teachers

\begin{tabular}{|c|c|c|c|c|}
\hline Items & Very Good\% & Good\% & Fair\% & Poor\% \\
\hline Lesson Plan & & & & \\
\hline 300 Level & 42 & 33 & 15 & 8 \\
\hline 400 Level & 65 & 35 & 0 & 0 \\
\hline Lesson Delivery & & & & \\
\hline 300 Level & 35 & 37 & 18 & 10 \\
\hline 400 Level & 68 & 32 & 0 & 0 \\
\hline Mode of Dressing & & & & \\
\hline 300 Level & 49 & 30 & 18 & 3 \\
\hline 400 Level & 56 & 42 & 2 & 0 \\
\hline Punctuality & & & & \\
\hline 300 Level & 62 & 30 & 8 & 0 \\
\hline 400 Level & 63 & 33 & 4 & 0 \\
\hline Comportment & & & & \\
\hline 300 Level & 64 & 36 & 0 & 0 \\
\hline 400 Level & 67 & 33 & 0 & 0 \\
\hline
\end{tabular}

Survey, 2016 
Table 3 above revealed that 400 level student-teachers have gained some experience during the first teaching practice exercise hence they seem to perform better in lesson plan and delivery than the 300 level student-teachers. Also, in the mode of dressing, 400 level studentteachers dress properly and better than the 300 level student-teachers. There is no much difference in their punctuality and comportment.

Research Hypothesis One:There is no combined significant influence of teaching practice orientation and supervision on the university student-teacher performance.

Table 4: Summary of ANOVA table Showing Combined Influence of Teaching Practice Orientation and Supervision on the University Student-teacher Performance in Ibadan, Oyo State

\begin{tabular}{|c|c|c|c|c|c|c|}
\hline Model & $\begin{array}{c}\text { Sum of } \\
\text { Squares }\end{array}$ & Df & $\begin{array}{c}\text { Mean } \\
\text { Square }\end{array}$ & $\mathbf{F}$ & Sig & Remarks \\
\hline Regression & 2149.476 & 2 & \multirow{2}{*}{$\begin{array}{c}1074.738 \\
98.872\end{array}$} & \multirow[b]{2}{*}{10.87} & \multirow[b]{2}{*}{0.011} & \multirow[b]{2}{*}{ Sig. } \\
\hline Residual & 19477.784 & 197 & & & & \\
\hline Total & 21627.26 & 199 & & & & \\
\hline \multicolumn{3}{|c|}{$\begin{array}{l}\mathrm{R}=0.201 \\
\mathrm{R} \text { Square }=0.576 \\
\text { Adjusted } \mathrm{R} \text { Square }=0.523 \\
\text { Std. } \text { Error of the Estimate }=9.901\end{array}$} & & & & \\
\hline
\end{tabular}

sig. $\mathrm{P}<0.005$

The findings of hypothesis one is presented in table 4, the hypothesis is set to test significant combined influence of teaching practice orientation and supervision on the university studentteacher performance in Ibadan, Oyo State. The table showed that the dependent variable was positively predicted by the independent variables $(\mathrm{F}=10.87, \mathrm{P}<0.05)$, rejecting the null hypothesis. The table also showed a coefficient of multiple correlation $(\mathrm{R}=0.201$ and $\mathrm{a}$ multiple $\mathrm{R}^{2}$ of 0.576 ). This means that $58 \%$ of the variance is accounted for by the predictor variables when taken together. The significance of the composite contribution was tested at $\mathrm{P}<$ 0.05 . The table also shows that the analysis of variance (ANOVA) for the regression yielded Fratio of 10.87 (significant at $5 \%$ level of significance). This implies that the joint contribution of the independent variables to the dependent variable was significant and that other variables may have accounted for the remaining variance. The linear combination of all the predictor variables was found to have significant relationship with the university student-teacher performance in Ibadan. $\left.\mathrm{F}_{(2,199)}=10.87\right) ; \mathrm{P}<0.05$.

Research Hypothesis Two: There is no relative significant influence of teaching practice orientation and supervision on the university student-teacher performance in the elected public secondary schools.

Table 5: Regression Table Showing the Relative Influence of Teaching Practice Orientation and Supervision on the University Student-teacher Performance in Ibadan, Oyo State

\begin{tabular}{|c|c|c|c|c|c|c|}
\hline \multirow{2}{*}{$\begin{array}{l}\text { Dependent } \\
\text { Variable }\end{array}$} & \multirow{2}{*}{$\begin{array}{l}\text { Independent } \\
\text { Variables }\end{array}$} & \multicolumn{2}{|c|}{$\begin{array}{l}\text { Un-standardized } \\
\text { Coefficient }\end{array}$} & \multirow{2}{*}{$\begin{array}{c}\begin{array}{c}\text { Stand. } \\
\text { Coefficient }\end{array} \\
\text { Beta } \\
\text { Contribution }\end{array}$} & \multirow[b]{2}{*}{$\mathbf{T}$} & \multirow[b]{2}{*}{ Sig. } \\
\hline & & B & $\begin{array}{c}\text { Std. } \\
\text { Error }\end{array}$ & & & \\
\hline $\begin{array}{l}\text { Student-teacher } \\
\text { Performance }\end{array}$ & $\begin{array}{l}\text { (Constant) } \\
\text { Teaching Practice } \\
\text { Orientation } \\
\text { Supervision }\end{array}$ & $\begin{array}{l}17.169 \\
0.257 \\
0.245\end{array}$ & $\begin{array}{l}3.207 \\
0.057 \\
0.080\end{array}$ & $\begin{array}{l}0.250 \\
0.170\end{array}$ & $\begin{array}{l}6.368 \\
4.497 \\
3.070\end{array}$ & $\begin{array}{l}0.000 \\
0.000 \\
0.002\end{array}$ \\
\hline
\end{tabular}


The information provided in table 5 shows the relative contribution among teaching practice orientation and supervision of student-teachers on their performance. The table showed that all the independent variables have significant contribution to the student-teachers performance at 0.05 level of significance, this is expressed in beta weights and shows in a way that; teaching practice orientation $(\beta=0.250, P<0.05)$, and supervision during teaching $(\beta=$ $0.170, \mathrm{P}<0.05)$. This showed that teaching practice orientation on student-teacher performance is more than supervision during the teaching practice.

The following values were obtained for each of the independent variables: teaching practice orientation $(\mathrm{P}=0.000$; and Supervision $\mathrm{P}=0.002$, from these it is shown that the $\mathrm{P}-$ value of each of the variables is less than 0.05 , this implies that there is significant relative contribution of the teaching practice orientation and supervision on the university student-teacher performance in Ibadan, Oyo State. Therefore, the null hypothesis is rejected at $5 \%$ level of significance.

\section{CONCLUSION}

Based on the data collected and analyzed, the following conclusions were made:

That student-teachers experience so many challenges during the teaching practice exercise. The challenges ranges from lack of facilities in the practicing schools; too many students in a classroom (over crowdedness and not enough ventilation in the classroom); feeling nervous when supervised by their lecturers/supervisors; accommodation and transportation issues; sometimes they are being rejected from the practicing schools, and also, the inability to instill discipline in the students, and problems of using various methods of teaching among others.

It is also concluded that teaching practice exercise immensely contributes to the studentteachers teaching skills in the area of building of confidence and competency, mode of dressing, lesson plan, lesson delivery, and sense of discipline to mention few. This is known as pedagogical content knowledge (PCK). It was also observed and concluded that 400 level student-teachers perform better than 300 level student-teachers in the area of lesson plan writing and delivery. And there is no much difference in the area of comportment and punctuality. Thus, it can be concluded that the 400 level student-teachers have gained experience during their first experience at 300 level.

Furthermore, the finding showed that the dependent variable (student-teacher performance), was positively predicted by the independent variables (teaching practice orientation and supervision). This showed that the joint contribution of the independent variables to the dependent variable was significant as well as the relative contribution of the independent variables. The implication of this is that teaching practice orientation and supervision have significant influence on the dependent variable (student-teacher performance).

\section{RECOMMENDATIONS}

Based on the findings of this study, the following recommendations were made:

1. The Faculty of Education in each university should have a well constituted teaching practice committee that will oversee the whole teaching practice exercise especially the area of supervision

2. The maximum number of students in a class should not exceed 30 to allow better classroom management by the student-teacher so that there can be effectiveness and better performance.

3. Student-teacher should make sure that lesson plan is assessed and signed by the cooperating teacher before going to the class to teach. 
4. Teaching practice committee of each university should make sure that student-teachers are posted to the practicing schools where they are needed and the number of studentteachers needed in order to avoid the situation of rejection of student-teachers

5. Teaching practice committee should organize an effective and adequate orientation for student-teachers before the commencement of the teaching practice exercise.

6.There should be a good rapport between the cooperating teachers and the studentteachers so as to enable the student-teacher achieve the desired outcomes from the exercise.

7.Government should provide adequate facilities to public schools in order to make teaching-learning process effective and efficient.

8. Government should take teaching practice seriously in the same way Students Industrial Work Experience Scheme (SIWES) is taken seriously as an important requirement for teaching being a professional discipline

9. Allowance should be given to student-teachers during the teaching practice exercise so as to encourage and motivate them just like their counterparts in engineering, accounting and the like.

\section{References}

\section{Journal Papers}

Bryk, A. (1988), Musings on the Moral Life of Schools. American Journal of Education, 96, 256-290

Damola, S.O. (1991), Teaching practice and university admission for NCE graduates. Ilorin Journal of Education. 11(1), 88-94

Cladinin, D.J., \& Connelly, F.M. (1986), Rhythms in teaching: The narrative study of teachers' personal practical knowledge of classrooms. Teaching and Teacher Education, 2,372-387.

Emerole, E.N. \& Muraina, K.O. (2015), Teaching practice anxiety sources as correlates of teaching performance among student-teachers in federal colleges ofeEducation in southwestern Nigeria. European Scientific Journal, Vol 11 (22), ISSn (e) 1857-7431, 1857-7881(P).

Saricoban, A. (2010), Problems encountered by student-teachers during their practicum studies. Procedia-social \& Behavioural Sciences 2(2), 707-711.

Schaefer, D. (2001), The Ohio State University supervision research programme summary report. Journal of Teaching Physical Education, 9, 69-74.

Shul-man, L. (1986). Those who understand: knowledge growth in teaching. Educational Researcher, 15, 4-21.

\section{Textbook}

Anning, A. (1988), Teachers' Theories about Children's Learning in J. Calderhead (Ed.), Teachers' Professional Learning (pp.128-145), London, UK: Falmer Press.

Clandinin, D.J., (1986), Classroom practice: Teacher images in action. Lewes: Falmer

Dibbon, S.B.G. (2004), Student-teachers and individual differences. New York: Plenum Press.

Schön, D. (1982). The reflective practitioner. New York: Basic Books.

\section{Conference Proceedings}

Ijaiya, N.Y.S. 1991. A guide to supervision of Instruction. Ilorin: My Grace Repro.co.

The Alberta Teachers' Association 2017. Nature of Teaching and Teaching as a profession. Edmonton, Alberta TSN 2R1

\section{Online Publications}

Bolarinwa, O. (2010), Effects of teaching practice on students in tertiary institutions in Nigeria, Munich, GRIN Verlag, http://www.grin.com/en/e-brok/182582/effects-of-teaching-practice-on-student-teachers-in-tertiaryinstitutions 
Faulkner, S.A. \& Cook, C.M. (2006), Testing vs teaching: The perceived impact of assessment demands on middle grades instructional practices. RMLE Online, Research in Middle Level Education, 29(7).

Available Online: http://dx.doi.org/10.1080/19404476.2006.11462030 (25 August, 2015).

\section{THESIS}

Hoben, N. (2006). Real Teachers, real classrooms and real experiences: The work of associates with pre-service teachers on practicum. A thesis completed in partial fulfilment of the requirements for the degree of Doctor of Education, The University of Auckland 